$$
\text { Sárai-Szabó Kelemen - Dömötör Mihály }
$$

\title{
A győri bencés gimnázium második államosított tanéve és a szerzetesek visszatérése
}

\section{The Second Nationalized School Year of the Benedictine Grammar School in Győr and the Return of the Monks}

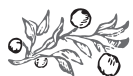

\section{Összefoglalás}

A második világháború lezárását követő koalíciós években az egyre fokozódó szovjet nyomásgyakorlásnak és a kommunista párt befolyásának növekedésével mindinkább szűkült az egyházak- és különböző felekezetek társadalmi mozgástere. A kiformálódó új hatalom a katolikus egyházat és azon belül a szerzetesrendeket titulálta fö ellenségnek, amelyek működésének ellehetetlenítésére fokozatosan vezettek újabb és újabb intézkedéseket. Már a nagybirtokrendszer 1945-ös államosítása is alapjaiban rengette meg a különböző szerzetesrendeket, hiszen működésük és intézményeik ellátásának anyagi alapjai rendültek meg ezzel és kerültek egycsapásra az államtól függő anyagi helyzetbe, erősítve így kiszolgáltatottságukat. A koalíciós éveket követően 1948-tól teljesen világossá vált, hogy az ország társadalmi, politikai- és gazdasági berendezkedését a szovjet mintára kiépülő kommunista diktatúra és az azt fenntartó nomenklatúra által meghatározott keretek fogják megszabni. 1948 nyarán megtörtént az ország oktatási intézményeinek jelentős hányadát kitévő egyházi fenntartású iskolák államosítása, új állami tantervek kidolgozása, amely folyamatnak a győri bencés gimnázium is áldozatul esett. 1948 szeptemberében az intézmény Állami

SÁrai-Szabó Kelemen, perjel, Szent Mór Bencés Perjelség, Győr (kelemosb@ gmail.com); DöмÖтör MıнÁly, PhD hallgató, Széchenyi István Egyetem, Regionális- és Gazdaságtudományi Doktori Iskola, (domotor.mihaly@sze.hu). 
Czuczor Gergely Általános Gimnázium néven kezdte meg a tanévet és lett két évig ezáltal a város egyik szekularizált oktatás intézménye. Az államosítás folyamatának és az első tanévet követően e tanulmányban a második ,államosított” tanévet tekintjük át, valamint az 1950-es év történéseit, amikor a gimnázium fenntartása újra visszakerült a magyar bencés rendhez. E két év során úgy tűnt, hogy a bencés gimnázium csak egy üde színfolt marad Győr történelmének palettáján, azonban a történelmi fejlődés másként alakította a folyamatokat és a győri bencés gimnázium továbbra is Győr és az ország meghatározó keresztény oktatási műhelyévé tudott válni. A győri gimnázium példájából továbbá fel tudjuk vázolni azokat a bel- és kultúrpolitikai technikákat is, melyeket a pártaállam az egyházak visszaszorításában és intézményeik, javaik államosítása során alkalmazott.

Kulcsszavak: oktatás, Győr, kultúra, államosítás, bencés rend

\section{Summary}

In the coalition years following the end of World War II, with the increase of Soviet pressure and the influence of the Communist Party, the social room for manoeuvre of churches and various denominations narrowed. The emerging new power declared the Catholic Church, and within that the monastic orders, the main enemy, which gradually led to more and more measures to make it impossible for them to function. The nationalization of the large estate system in 1945 already shook the various orders of monks fundamentally, undermining the financial foundations of their operation and the care provided in their institutions, and making them instantly dependent on the state, thus increasing their vulnerability. After the years of the coalition, it became quite clear from 1948 that the social, political and economic system of the country would be determined by the framework defined by the communist dictatorship based on the Soviet model and the nomenclature that maintained it. In the summer of 1948, church-maintained schools, which constituted a significant proportion of the country's educational institutions, were nationalized, and new state curricula were developed, a process to which the Benedictine grammar school in Győr also fell victim. In September 1948, the institution began the school year as Gergely Czuczor State Secondary Grammar School and became one of the city's secularized educational institutions for two years. In this study, we review the second "nationalized" school year after the process of nationalization and the first school year, as well as the events of the 1950s, when the maintenance of the grammar school was returned to the Hungarian Benedictine order. During these two years, the Benedictine grammar school seemed to add only a dash of colour to the palette of Győr's history, but historical development shaped the processes differently and the Benedictine grammar school in Győr was able to become the dominant Christian educational workshop in Győr and the country. From the example of the grammar school in Győr, we can also outline the domestic and cultural policy techniques that the party state used in repressing the churches and in the nationalization of their institutions and goods.

Keywords: education, Győr, culture, nationalization, Benedictine order 
Sárai-Szabó Kelemen - Dömötör Mihály: A gyơri bencés gimnázium második államosított tanéve

Bevezetés: 1950-RE KiAlakuló POLITIKAI KÖRnYEZET, TÁRSADAlmi

HELYZETKÉP

A második világháború lezárását követően a koalíciós éveknek is nevezett három esztendő következett, mely során a magyar kommunisták szovjet támogatással folyamatosan építették ki hatalmukat a stratégiailag meghatározó hatalmi ágak és gazdasági szektorok terén. A szovjet nyomásgyakorlás egyre inkább növelte erejét, hogy az állam berendezkedését egypártrendszerré alakítsa át, mely folyamat eredményeként 1948-ra a Kommunista Párt vált a hatalom kizárólagos birtokosává, felszámolva a parlamentarizmus minden eszközét. Ahhoz, hogy a Kommunista Párt sikeres tudjon lenni az országban, szükséges volt a megfelelő ideológia megteremtése, amihez szükséges volt az oktatás teljes állami kontroll alá vétele, tehát az egyházi- és felekezeti intézmények államosítása. Az államosítás - a marxista gazdasági ideológia jegyében - az ipari-, mezőgazdasági - és kereskedelmi szektorban is zajlott, mely folyamattal egyidőben alakult ki a tervgazdálkodás szervezeti formái, melyben az erőltetett központosítás és centralizált hierarchia dominált (Romsics, 2010). A nagybirtokok 1945-ös államosítása nagy hatással bírt, hiszen így az államtól anyagilag függő helyzetbe kerültek az egyházak és az egyes szerzetesrendek is. Érdemes megjegyezni, hogy a kollektivizálás és központosítás a társadalom számára azért vált még megrázóbbá, mert a folyamat párosult egy koncentrált egyház- és vallásellenességgel (Ö. Kovács, 2009).

A gazdasági jellegű támadások után más fronton is támadni kezdték az egyházakat- és szerzetesrendeket, hiszen a társadalom kommunista ideológiájú „hatékony” átalakításához a hatalomnak szüksége volt a kulturális-, az oktatási-, és a vallási élet intézményeit is felügyelete alá vonni és azokat saját ideológiájának eszközévé tenni. Már 1945-ben megindult az oktatásügy reformja az Ideiglenes Nemzeti Kormány irányításával, amely nem csak az intézményi struktúra átalakítását jelentette, hanem az oktatás tartalmának a módosítását is, mely célul tűzte ki a vallásos világnézet kiszorítását az oktatás területéről, az ifjúság neveléséből (Romsics, 2010). 1946 júliusában feloszlatták a Magyar Cserkészszövetséget, a KALÁSZ, a KALOT és a Katolikus Legényegyletek csoportjait, majd 1948-ban - a „fordulat évében” - a kommunista hatalom már reálisnak és szükségesnek érezte az egyházi oktatási intézmények államosításának nyélbe ütését. Az 1947-1948-as tanévben az általános iskolák 63\%-a, a középiskolák 49\%-a, az óvónőképzők 60\%-a, illetve a tanítóképzők 74\%-a egyházi fenntartású oktatási intézmény volt (Barkó 2014; Romsics, 2010).

1948 tavaszán sikeresen megegyeztek a református és evangélikus egyházakkal, majd ősszel alá is írták a megállapodásokat. A katolikus egyházzal azonban jóval lassabban és bonyolultabban haladt az államosítás végrehajtása. Június 11 -én a nem állami iskolák és kollégiumok épületeit és felszerelését zárolták, majd június 16-án az Országgyűlés megszavazta a nem állami fenntartású iskolák államosításáról szóló XXXIII. tc. törvényt, amelynek értelmében 6.500 felekezeti és községi iskola került állami tulajdonba (Romsics 2010; Barkó 2014; Mészáros 1994). Az evangélikusok és izraeliták 1948 folyamán bizonyos megállapodásokat kötöttek az állammal működési kereteiket illetően, azonban a katolikus egyház fenntartásában nem maradt egyetlen oktatási intézmény sem (Barkó 2014, Romsics 2010). A törvény elfogadását követően azon szerzetesrendek, amelyek elsősorban tanítással foglalkoztak, 
engedélyt kértek a püspöki kartól annak érdekében, hogy tárgyalásokat folytathassanak az állami hatóságokkal. A tárgyalófelek között volt Sárközy Pál kormányzó apát, Sík Sándor piarista tartományfőnök, Borbély Istuán jezsuita provinciális, valamint Endrédy Vendel zirci főapát. A tárgyalások kimenetele sikertelennek bizonyult és további találkozókra a szerzetesrendek elöljáróinak csak római engedéllyel volt lehetséges, mert a magyar püspöki kar elhatárolta magát az állammal való megegyezésektől (Rétfalvi, 2017).

Az 1948-as törvény értelmében a Pannonhalmi Szent Benedek rend által fenntartott nyolc gimnáziumot is államosították, köztük az 1626-ban jezsuiták által alapított és 1802től bencés fenttartásban működő győri Czuczor Gergely Bencés Gimnáziumot is (Bánhegyi 1977; Tóth 2011). Az államosítás következményeként az intézmény két tanéven keresztül Győri Állami Czuczor Gergely Gimnáziumként működött (Barkó, 2014; Sárai-Szabó Fekete, 2021).

A kommunista államhatalom 1950 nyarára már elég erősnek és biztosnak érezte magát ahhoz, hogy megkezdje a szerzetesek deportálását székházaikból, amit követően az egyház már kénytelen volt tárgyalóasztalhoz ülni és megállapodásokat keresni a kommunista államapparátussal. Ez év szeptember 7-én megszületett a megegyezés az állam és a katolikus egyház között mely értelmében a győri gimnáziumot visszakapta a Pannonhalmi Szent Benedek Rend és így egyikévé lett annak a nyolc felekezeti gimnáziumnak, amely a négy évtizedes kommunista egypártrendszer idején működhetett és válhatott ezáltal a keresztény oktatás egyik „lángőrzőjévé” (Bánhegyi, 1977).

A tanulmány kissé „hiánypótló” szándékkal vizsgálja a gimnázium történelmének e két évének második felét, valamint a visszakerülés folyamatát. Két esztendő nem túl sok idő ahhoz, hogy gyökeres strukturális változásokra kerüljön sor, azonban megfelelő időszak ahhoz, hogy új ideológiák mentén próbálják egy tradicionális intézmény jövőjét megszabni, az ott tanuló ifjúság világképét ,,alakítani”. Elsődleges forrásként a gimnáziumi jegyzőkönyveket, számbavételi dokumentumokat, illetve a politikai légkörnek megfelelő propagandisztikus hangulatjelentéseket, ideológiai megközelítésű igazgatói- és szaktanári jelentéseket használtuk fel.

1948 nyarán úgy tűnt, hogy a magyar oktatás biztos bástyáját jelentő győri bencés gimnázium csupán a történelmi emlékezeté marad és megszűnik a jelenben működő intézménynek lenni. A gimnázium történelmi kontinuitása e két év során „megszakadni” látszott és a bencések győri története lezárul. Fontos megjegyezni azt a kultúrtörténeti szempontot is, hogy az ország történelme során nem volt példa ilyen fokú intézményrendszerbeli átalakításokra, valamint az egyházi-, felekezeti és kulturális szervezetek ilyen drasztikus diszkriminációjára. A győri bencés gimnázium államosítási folyamata és a két ,államosított” tanév rávilágít arra, hogy milyen hatalomtechnikai módszerekkel és bürokratikus eszközökkel manipulálta és irányította a kommunista államhatalom az ország társadalmi és gazdasági életét, belpolitikai folyamatait. A, ,sikeres” államosítási folyamat és a kibontakozással jellemezhető első ,államosított" tanévet követően áttekintjük a második évet, illetve az 1950-es visszatérés belpolitikai körülményeit és folyamatát. 
Sárai-Szabó Kelemen - Dömötör Mihály: A gyơri bencés gimnázium második államosított tanéve

\section{Az Államosított iskola második tanéve 1949/1950}

A miniszteri rendelet értelmében a gimnázium az 1949/50-es tanévben egy új általános gimnáziumi osztályt indíthatott (3299/1948-49., GYBGL, 1947-1948, 2. köteg). Az 1949/1950es tanév a megszokott módon, a szükséges javítóvizsgák megtartásával kezdődött. 1949. augusztus 29-én összesen 32 tanuló tett javítóvizsgát, akik közül 9 tanulónak latinból, 17 tanulónak mennyiségtanból, 1 tanulónak természettanból, 3 tanulónak német nyelvből és 2 tanulónak magyar nyelvből kellett a szükséges vizsgát megtennie (2/1949-50., GYBGL, 1948-1950, 1. köteg). Az általános javítóvizsgák mellett magán- vagy különbözeti vizsgákra is sor került, amelyek egy nappal később augusztus 30-án zajlottak le. Ilyen, magán típusú vizsgát összesen 5 tanulónak kellett megtennie (1-1, 1-2, 1-3, 1-4, 1-6/1949-50., GYBGL, 1948-1950, 1. köteg). A vizsgák sikerességét mutatja, hogy a résztvevő tanulók mindegyike elérte a legalább elégséges szintet, így évet ismételni nem kellett nekik.

A javítóvizsgák megszervezés eután a gimnázium személyi állományát illetően jelentős változás következett be, hiszen az előző tanévben megbízott igazgatót, Zalai fózsefet augusztus 31-i hatállyal a Vallás és Közoktatásügyi Minisztérium leváltotta tisztségéről és helyére Csukás István ugyancsak megbízott igazgató került (18/1948-49., GYBGL, 1948-1950, 1. köteg). A gimnázium átadására augusztus 31 -én sor került, ahol a volt megbízott igazgató Zalai fózsef, mint átadó mellet a győri tankerületi főigazgatás részéről Ládi Károly gimnáziumi tanár és az új megbízott igazgató Csukás Istuán, mint átvevő voltak jelen (53/1949-50., GYBGL, 19481950, 1. köteg). A gimnázium átadásának jegyzőkönyvében feltüntették, hogy Ládi Károly a gimnázium pénztárát és pénztári okmányait átvizsgálta és jóváhagyta, valamint megállapította az elszámolási végeredményt is (53/1949-50., GYBGL, 1948-1950, 1. köteg).

Az igazgatói állást ért változások mellett a tanári karban is történtek változások, személycserék. Összességében csökkent a megelőző tanévhez képest a tanári kar létszáma, 20 főről 15-re. Ez főként a hitoktatás óraszámának erőteljes visszaeséséből, valamint a kisebb létszámú óraadói gárdából következik (359-423/1949-50., GYBGL, 1948-1950, 1. köteg). A fóállású tanárok létszáma az előző tanévben - a megbízott igazgatóval együtt - 9 fő volt, amely az 1949/50-es tanévre ugyancsak 9 fő maradt. Az óraadó tanárok létszáma azonban 8 főről 5 főre csökkent (359-423/1949-50., GYBGL, 1948-1950, 1. köteg). Fontos megjegyezni, hogy az 1948/49-es tanévben még 3 főt számláló hitoktatói tevékenység az új tanévre 1 före csökkent, azonban a tantárgyfelosztás nem is nevez meg aktuális gimnáziumi hitoktatót (180/1949-50., GYBGL, 1948-1950, 1. köteg). Gaál Lajos testnevelő tanárt - aki már az 1947/1948-as tanévben is a gimnázium testnevelő tanára volt - október 6-án a Tankerületi Főigazgatóság a Nagy Jenő utcai általános iskolába áthelyezte (5695/1949., GYBGL, 19481950, 1. köteg). Rajta kívül Makkos Jenốt - aki 1948. augusztus 19-én érkezett a gimnáziumba - 1949 szeptember 7-én Zalai fózsef megbízott igazgató felmentette a gimnáziumi működés alól (38-2/1949-50., GYBGL, 1948-1950, 1. köteg). Új szaktanár is került a tantestületbe, Koncz fózsef személyében, aki a rajz tantárgy tanítását végezte a gimnáziumban, valamint fóállású tanárként még Bors Miklós érkezett a gimnáziumba, aki történelem,latin, francia szakos volt - is (7260/1949., GYBGL, 1948-1950, 1. köteg). A tanári kar többi tagja maradt az előző tanév szerint. 
1. táblázat: A Györi Állami Czuczor Gergely Gimnázium tantárgyfelosztása az 1948/1949-es tanévre

\begin{tabular}{|c|c|c|}
\hline Név & Minősítés & Szaktárgy \\
\hline Csukás István & mb. igazgató & magyar - latin \\
\hline Dr. Bajomi Miklós & óraadó tanár & magyar - latin \\
\hline Bálint Béla & rendes tanár & testnevelés \\
\hline Bors Miklós & rendes tanár & történelem - latin - francia \\
\hline Federmayer István & főhivatású óraadó & magyar - latin - orosz \\
\hline Frank Emilné & rendes tanár & francia - német \\
\hline Dr. Horváth Edit & rendes tanár & latin - német - angol - orosz \\
\hline Horváth Dezső & rendes tanár & ábrázoló geometria - rajz \\
\hline Molnár Endre & rendes tanár & történelem - földrajz \\
\hline Ónodi Milán & rendes tanár & magyar - német \\
\hline Szlavonits Ferenc & rendes tanár & \\
\hline Tóth Endre & óraadó tanár & ének - zene \\
\hline Schaub László & óraadó tanár & természettan - mennyiségtan \\
\hline Budai Kálmán & óraadó tanár & mennyiségtan \\
\hline
\end{tabular}

Forrás: GYBGL, Gimnáziumi iratok 1948-1950. 1. köteg

A gimnázium egyéb alkalmazottai közül az altisztek (Bertal Ferencné, Horváth Lajos, Látó Kálmán) ugyancsak maradtak az előző tanév óta. A gimnázium személyi állományában bekövetkezett változások után az iskola tanulóinak magatartásbéli viszonyaira, illetve az esetleges fegyelmi ügyeire térünk át, hiszen a gimnázium, a tanári kar tevékenységét pedagógiai szempontból ezen a téren könnyebb vizsgálni. Az 1949/50-es tanévben az Állami Czuczor Gergely Gimnáziumba összesen 244 tanuló járt évfolyamonként a következő megoszlásban.

2. táblázat: Az Állami Czuczor Gergely Gimnázium tanulói létszáma évfolyamonként

\begin{tabular}{c|c}
\hline Osztály & Tanuló \\
\hline I. & 49 fö \\
\hline II. a. & 27 fó \\
\hline II. b. & 25 fö \\
\hline III. a. & 37 fö \\
\hline III. b. & 27 fó \\
\hline IV. a. & 40 fó \\
\hline IV. b. & 39 fó
\end{tabular}

Forrás: GYBGL, Gimnáziumi iratok 1948-1950. 1. köteg 
A tanév első tantestületi értekezletére 1949. szeptember 27-én került sor, ahol az új igazgató Csukás István a fegyelem területén a múlt évihez képest kisebbfajta javulást látott, de véleménye szerint még van „,csiszolni való”. Kiemelte a nevelők munkafegyelmét, amely a „pontos órakezdés, az óraközi felügyeletek pontos és tevékeny megtartása, az órákra való lelkiismeretes felkészülés”(214/1949-50., GYBGL, 1948-1950, 1. köteg). Fontos igazgatói utasítás volt továbbá, hogy a diákok részéről történt fegyelmezetlenségeket az osztályok közös ügyként kezeljék és a komolyabb esetek bírálásába a Diákszövetség fegyelmi tanácsát is vonják be (214/1949-50., GYBGL, 1948-1950, 1. köteg). Ezek után érdekes mozzanat, hogy október 21 -én a gimnázium tanári testülete rendkívüli értekezletet tartott az iskolai fegyelem rossz állapotának orvoslása céljából. Az igazgató és tanári kar mellett jelen volt az állampárt az MDP iskolafelelőse is (254/1949-50., GYBGL, 1948-1950, 1. köteg). Az igazgató, mint az értekezlet elnöke kiemelte, hogy a gimnáziumi tanulók fegyelmi állapota rossz, amely főként magatartásbéli problémákat és a tanuláshoz való destruktív hozzá állást takarja. Az egyre teljesebbé váló és az oktatás minden szintjét átható osztályharcos politika a gimnáziumban is kezdte éreztetni hatását, mivel az igazgató kiemelte, hogy a rendbontó és nihil diákok java része klerikális és osztályidegen társadalmi környezetből érkeznek, mely negatív viselkedésüket alátámasztja.

Csukás igazgató kiemeli, hogy „a tanári testületnek tehát az iskolai fegyelem kérdését mindenekelótt politikai kérdésként kell kezelni" (254/1949-50., GYBGL, 1948-1950). Az igazgató ezek után 8 tanulót név szerint is felsorolt, akiknek, ha magaviselete nem változik, a közeljövőben elbocsátandók. Az egyes tanulóknál a családi környezetet és főként az apa foglalkozását erőteljesen emelte ki az igazgató (254/1949-50., GYBGL, 1948-1950, 1. köteg). Ezt követően a Győr - Moson vármegye Tankerület Főigazgatója a 8 tanulóból 5-öt a vármegye összes középiskolájából kizárta további 5 diák pedig igazgatói megrovását jóváhagyta. A retorzió oka: demokrácia ellenes magatartás, valamint az iskolai munka tervszerű szabotálása (6434/1949., GYGBL, 1948-1950, 1. köteg).

Az év folyamán a következő nevelőtestületi értekezletre november 25-én került sor, ahol az igazgató a fegyelmezés fontosságát újfent ideológiai alapokkal támasztotta alá. Az osztályfönököknek a következő utasítást adta: „, a fegyelem a demokráciában új értelmezést nyert. Nem magánügy többé, hanem közügy". A fegyelmezetlen tanuló tehát nem csak a saját, hanem az egész osztály munkáját zavarja, tehát az egész közösség ellen vét, vagyis, mint „,közösség ellen elkövetett vétség esik elbirálás alá” (254/1949-50., GYBGL, 1948-1950, 1. köteg). A tanév következő időszakában is voltak fegyelmi eljárások január 21-én, illetve február 7-én, amikor 2 tanulót magatartásbéli vétség indokával bocsátott el az igazgató a gimnáziumból (577/1950., 633/1950., GYBGL, 1948-1950, 1. köteg). Az április 15-én megtartott tantestületi értekezleten az igazgató újfent a fegyelem lazulásáról beszélt, melyet egyértelműen a klerikális múlt, illetve a klerikális környezet negatív hatásainak tudott be. Hibának rótta fel, hogy a nevelői testület fele még mindig gyakorolja vallását, valamint, hogy a diákok közül még a munkás származásúak is járnak reggelente misére. Az igazgató rávilágít, hogy a nevelők felelőssége ennek ,javítása” tehát „az ifjúság haladó politikai neveléséert” (871/1950., GYBGL, 1948-1950, 1. köteg).

Ahogy a fegyelmi ügyek vizsgálatából is látszik az 1949/50-es tanévre a gimnázium vezetőségén belül és magában a gimnáziumi oktatásban is egyre erőteljesebben kezdett ér- 
vényesülni az a kommunista retorika, amely az osztályharcos szellemre és a sztahanovista munkaversenyre épül, illetve amely a nevelés terén a fó támpontokat fogja adni. A pedagógia szemszögéből az egyes tantestületi értekezleteken kiemelték a makarenkói módszer lényegét és sürgették annak mihamarabbi alkalmazását, bevezetését is (447/1949., GYBGL, 19481950, 1. köteg). Maga a kiéleződő munkaverseny szelleme a tantestületen belül is egyre inkább éreztette hatását, amit mi sem példáz jobban, mint hogy december 7-én az igazgató vezetésével megtartották az első versenyértekezletet. Itt a tanári testület tagjai beszámoltak a felajánlásaik teljesítéséről, amelyek főként a tanulók ideológiai - politikai átnevelését szolgálták (427/1949., GYBGL, 1948-1950, 1. köteg). A második versenyértekezletre elég hamar, december 15-én került sor, ahol a gimnázium versenyfelelőse megállapította, hogy a kollektív munkafelajánlások teljesítése ,igen jó úton halad” (465/1949., GYBGL, 1948-1950, 1. köteg). Csukás István igazgató október 11 -én rendkívüli értekezletet hívott össze, amelynek egyik fő témája a fegyelem és a fegyelmezés kérdése volt. A témakört illetően az igazgató egy tíz nappal korábbi Rákosi beszédre hivatkozva a pedagógusok „éberségére” és a „,nemzetközi helyzet fokozottságára”, valamint a „reakciós” tanulók átnevelésére hívta fel erőteljesen a figyelmet (246/1949-50., GYBGL, 1948-1950, 1. köteg). Az igazgató kiemelte, hogy a gimnázium „szociális összetétele igen rossz”, mivel a tanulók többsége „reakciós/kulák, polgár, kereskedő, deklasszált elem”. Nagy gondnak vélte, hogy a gimnáziumban erőteljesen jelen van a klerikalizmus, a vallásosság szelleme, mind a tanulók, mind a tantestület körében, amely a gimnázium egyházi múltjával is magyarázható és fontos eszköznek az ideológiát jelölte meg a „sikeres harc” érdekében (246/1949-50., GYBGL, 1948-1950, 1. köteg). A „klerikális reakció" megfékezéséhez tartozik az a tény is, hogy az 1949/50-es tanévtől kezdve - az Elnöki Tanács által kiadott rendelet értelmében - a vallástan rendkívüli tantárggyá minősítették és maximális óraszámát heti kettőben állapították meg, tehát kivették a kötelező tantárgyak köréből (5207/1949., GYBGL, 1948-1950, 1. köteg).

1950 áprilisában a nevelő testület Csukás igazgató vezetésével munkatervet fogadott el, amely szeptemberig különböző - főként ideológiai, politikai - feladatok elvégzésére osztotta be a tantestületet. Ez jelenti a tanulók ideológiai alapú nevelését, de jelenti magának a tanári gárdának is az ideológiai képzését, amelyhez délutáni szemináriumok, továbbképzések álltak a rendelkezésükre. A gimnáziumi nevelést teljes mértékben áthatotta a versenyszellem, így a feladatokat teljesítésük mértékével az osztályok számára havi szintre bontották le. Ezekben az ideológiai alapú feladatokban a gimnáziumot két szervezet, a diákszövetség és szülői munkaközösség segítette, támogatta. Az igazgató hangsúlyozta azt is, hogy a gimnázium, illetve a két szervezet folyamatosan kapcsolatot tartott és ideológiai témában segítséget kért a Magyar Dolgozók Pártjától (817/1950., GYBGL, 1948-1950, 1. köteg). November hónaptól a gimnázium helyet biztosított ún. Szülők Iskolájának, ahol - túlnyomó részt a diákok szüleinek - főként ideológiai és politikai témájú szemináriumokat tartottak, amelyeken két hónap alatt, öt alkalom során összesen 375 szülő vett részt (522/1950., GYBGL, 1948-1950, 1. köteg). A Tankerületi Főigazgatóságtól rendszeresen érkeztek körözvények a gimnáziumba, amelyek rendszerint ünnepségek megtartására, békebizottságok alakítására, úttörőprogramokon való részvétele buzdították, mind a diákságot, mint a tantestületet (1072-10/1950., GYBGL, 1948-1950, 1. köteg). A körözvények már felszólították az új ünnepkörök méltó 
megünneplésére az iskolák figyelmét. Ilyen a november 7-i nagy októberi szocialista forradalom vagy Sztálin születésnapja, melyekre a diákoknak dolgozatokat, munkákat kellett készíteniük és a legjobbakat felterjesztették a Tankerületi Főigazgatósághoz (91/1949., GYBGL, 1948-1950, 1. köteg). Ugyancsak ilyen nagy hatású rendezvény az ifjúság napja rendezvény (október 29-én), amelyet a „Hős Szovjet Komszomol 31 éves fennállásának ünnepére szervezett a Főigazgatóság. Erre a megjelenés a gimnázium számára is kötelező (6304/1949., GYBGL, 1948-1950, 1. köteg).

A fegyelmi és magatartásbéli viszonyok mellett egy gimnázium színvonalát, illetve egy tantestület munkájának eredményességét a tárgyi tudás gyarapodása, a szaktárgyak tanításának a minősége is fémjelzi. Emiatt is fontos, hogy a tantestületi értekezletek jegyzőkönyvei mellett a különböző szaktanárok, illetve szakfelügyelők jelentéseit, véleményét is szemügyre vegyük, mely a tanulóknak az 1949/50-es tanévben történt szakmai fejlődését, tárgyi tudásának növekedését tükrözik. Természetesen az ideológiai háttér és szemlélet itt, a különböző szaktárgyi jelentések során is erőteljesen megmutatkozik. Fontos megállapítani, hogy az 1949/50 es tanévtől vezették be a kötelező orosz nyelv oktatását, valamint - ahogy már előbb említésre került - a vallástant kivették a kötelező tantárgyak csoportjából (766/194950., GYBGL, 1948-1950, 1. köteg).

A tanév folyamán rendszeresek voltak a tanulmányi felügyeletek, melyekről jegyzőkönyv formájában ránk maradt az orosz nyelv, a latin nyelv, a francia és a német nyelv, a történelem, ének, vegytan, illetve a földrajz tárgyak felügyeletének a beszámolói (691/1950., 766/1949-50., 732/1950., 1212-17/1950., 1212-18/1950., GYBGL, 1948-1950, 1. köteg). A szakfelügyelők minden esetben meg voltak elégedve a szaktanárok felkészültségével és órai munkájukkal. Különösön az újdonsült orosz nyelvtanárok (Federmayer István, Dr. Horváth Edit) szakmai felkészültségét emelte ki a szakfelügyelő (766/1949-50., GYBGL, 1948-1950, 1. köteg). Az órai fegyelem terén már mutatkoztak hiányosságok, amelyeket a jegyzőkönyvekben fel is tüntetnek, azonban ezek nem mondhatók súlyos kihágásoknak. Az esetleges szaktárgyi lemaradások okát egyértelműen a tankönyvhiány, vagy az ideológiai szempontból „nem alkalmas” tankönyvek jelentik. Az ideológiai és politikai szempontú értékelés minden tantárgynál, de különösen a történelemnél nagy hangsúlyt kapott, de a szakfelügyelő ezen a téren is elégedettséget közölt az érintett szaktanárral szemben (1212-16/1950., GYBGL, 1948-1950, 1. köteg).

Október 19-i jelentésében Csukás igazgató felvázolta, hogy ez a tanév már teljes egészében a szocializmusra nevelés jegyében indult, amelynek pontos menetét a nevelőtestülettel külön, év eleji konferencián tárgyalták meg. Az év eleji tapasztalatokról szólva az igazgató megállapította, hogy nagy az érdeklődés a diákok körében a különböző tantárgyak iránt - főként az újdonsült orosz nyelv iránt! -, azonban több esetben a tananyag túl nagy, illetve nem minden esetben áll rendelkezésre megfelelő tankönyv (pl.: földrajz, orosz nyelv) (238/1949-50., GYBGL, 1948-1950, 1. köteg). A következő igazgatói jelentés február 17-én készült, amelyben az igazgató újfent néhány tárgy nehézségére, és túlterheltségére hívta fel a figyelmet (természettudományos tárgyak), valamint ideológiai síkon problémának ítélte a filozófia és a politikai gazdaságtan megszűnését, amely a tantestületen belül óraterhelési aránytalanságot is eredményezett. A diákok körében pedig kiemelte, hogy a munkás- és parasztszármazású 
diákok általában a matematikában bizonyulnak gyengébbnek, a volt bencés diákok pedig politikailag mutatnak erőteljes gyengeségeket (661/1950., GYBGL, 1948-1950, 1. köteg).

A gimnázium állapotáról való félévi jelentésében Csukás Istuán igazgató a tanulók lemorzsolódásával kezdi, melynél rögtön megjegyzi, hogy a dolgozó osztályokra vonatkozóan ez nem fordul elő. Az egyes tanulók esetében a társadalmi osztályt és a vagyoni helyzetet minden esetben feltüntetik, hogy igazolni tudják azok „reakciós” voltát. Az igazgató a tanulmányi színvonalat minden tantárgyból megfelelőnek ítélte, egyedül az év eleji tankönyvhiány támasztotta nehézségekre hívta fel a figyelmet. A munkafegyelem terén már kevésbé pozitív véleményen van. Hat tanulót elbocsájtottak az év első felében fegyelmezetlenségi problémák végett, melyet az igazgató jelentett a tankerület irányába (395/1950., GYBGL, 1948-1950, 1. köteg). Szerinte a kihágások a „klerikális befolyás által irányított tervszerü szabotázscselekmény”, amellyel a tanári karnak folyamatosan meg kellett küzdenie. Az igazgató erőteljesen kiemeli a gimnáziumi munkaversenyeket is, melyek „áldásos” hatása az otthon töltött szünidők után gyengülni látszik. Érdekes megállapítás az igazgatótól, hogy az ügyvitel terén panasszal él felsőbb szervek irányába. Megjegyzi, hogy a féléves zárás, a sztálini munkaverseny és ünnepségi előkészületkor azonnali határidővel kértek statisztikai kimutatásokat, jelentéseket, amelyek nagyon megnehezítették a munkát. Megjegyzi továbbá, hogy a tanári gárda továbbképzése és ideológiai tanítása folyamatosan zajlik (624/1950., GYBGL, 1948-1950, 1. köteg). Pedagógiai szempontból érdekes levéltári forrás a tanári testületnek a január 28-án tartott I. félévi osztályozó értekezletéről készült jegyzőkönyv. Az igazgató ugyanis az értekezlet elején leszögezte, hogy az egyes tanulók értékelésénél nem csak a lexikális tudás elsajátításának mértékét veszik figyelembe, hanem egyúttal politikai feladatot is végeznek, tehát azt is értékelik, hogy mennyire azonosult a tanuló a demokratikus eszmékkel. Az igazgató ezt így fogalmazza meg: „a szaktudáson kiviul - politikai fejlettség, a demokratikus meggyöződés őszintesége, klerikális beállitottság, diákszövetségi, tanulóköri munka, újságolvasás, a tanulónak a munkához való viszonya, a munkaerkölcs, a munkaverseny szellemétól való átfütöttsége. Tehát az egész embert osztályozzuk” (632/1950., GYBGL, 1948-1950, 1. köteg). Ez a korszakra jellemző - a marxista - leninista jegyekkel erőteljesen átfütött munkaverseny alapú pedagógiai módszernek egy iskolapéldája.

Február 27-én kelt jelentésében az igazgató összefoglalja a tanulmányi eredményeket, a tanulmányi színvonalat szeptembertől kezdődően. Az egyes osztályok esetében a különböző tantárgyakban való haladást részletezte és az esetek túlnyomó részében kielégítőnek és szakszerűnek ítélte meg azokat. A tanulók munkafegyelmét illetően a tanórákról való késést jelölte meg fő problémának, amelyet ezentúl szigorúbban fognak venni. Egy tanuló eltávolításáról is számot adott Csukás igazgató. A tantestület és a diákszövetség folyamatosan részt vett politikai szemináriumokon, melynek gyakoriságát az igazgató kielégítőnek tartotta (697/1950., GYBGL, 1948-1950, 1. köteg).

Az április havi jelentésében Csukás igazgató kifejtette, hogy a hónapban nem volt lemorzsolódás a tanulókon belül, valamint, hogy az előírt tananyagot minden osztályban a tanmenetnek megfelelően elvégezték. Ez alól kivételt csak a II. a. és a III. a. osztályban a földrajz tárgya jelentett a szaktanár (Molnár Endre) betegsége és a szakhelyettesítés nehézsége miatt. Az igazgató hozzátette, hogy a tananyag elsajátításának minősége a szaktanárok véleménye szerint megfelelő. A tanulók munkafegyelme is tovább javult a reggeli késések megszűntek 
és a mulasztott órák száma is erőteljes csökkenést mutatott. Az igazgató kitért az orosz nyelv és a természettudományos tárgyak oktatására, melyek esetében a szakfelügyelők kielégítőnek ítélték az eredményeket. A kommunista ideológia erőteljes nyomulását jelzi az is, hogy az igazgató külön kitér a tantestület továbbképzési aktivitásáról, a politikai szemináriumok való részvétel gyakoriságára, melyeket ugyancsak megfelelőnek ítélt az igazgató (884/1950., GYBGL, 1948-1950, 1. köteg).

Ugyancsak április havi állapotjelentésében az igazgató a szaktárgyak megfelelő elsajátítása mellett hangsúlyozta, hogy a diákszövetség munkája a munkaverseny vezetésében és az iskolai politikai légkör fejlesztésében nagyfokú hiányosságokat mutatott, melynek a fő oka a megfelelő számú káder hiánya. Emellett kiemelte, hogy maga az igazgatói munkakör és a nevelőtestület is adminisztratív túlterheléstől szenved, mely megnehezíti a klerikális reakció elleni küzdelmet is. Ezért javasolta a nevelő testület feltöltését, mely a terheket minden bizonnyal csökkentené. A tantestület politikai szakszervezeti szemináriumokat végzett, melyet az igazgató külön kiemelt (885/1950., GYBGL, 1948-1950, 1. köteg).

A tantestületi értekezletek jegyzőkönyveiből, igazgatói jelentéseiből jól látszik, hogy az 1949/50-es tanév már egészében a szocialista eszme jegyében, a marxista, leninista ideológia talaján zajlott, hiszen a szaktárgyi ismeretek mellett szinte akkora súllyal szerepelt a politikai ésideológiai képzettség megléte, mind a tanulók, mind a tantestület körében.

A gimnáziumban a szülői munkaközösség is aktív szerepet vállalt a programok szervezésében és az ünnepségek rendezésében. Ezekről az eseményekről a munkaközösség havi beszámolóiból tudunk bővebb információkat kapni. Fő feladataikat négy csoportba gyüjtötték:

- egy iskolai műsoros est megrendezése,

- családlátogatás a tanulók szociális viszonyainak a megismerése végett,

- tanulókörök ellenőrzése,

- közreműködés az iskolai dekorációban.

A beszámolókból tudjuk, hogy ezek programpontok csak részlegesen valósultak meg (305/1949-50., GYBGL, 1948-1950, 1. köteg). A feladatok megvalósítása az egész tanévet végig kíséri és néhol többet, néhol kevesebbet tudnak belőlük a szülők megvalósítani, aminek magyarázatára a kevés időt és a sok otthoni feladatot adták (420/1949-50., GYBGL, 19481950, 1. köteg). Fontos tény, hogy a Szülői Munkaközösség rendszerint a Diákszövetséggel együtt végezte kitűzött feladatait és az értekezleten részt vett egy delegált is az MDP-ből, a megfelelő ideológiai sík biztosítása végett (879/1950., GYBGL, 1948-1950, 1. köteg).

A tanév lezárásaként még fontos megjegyezni, hogy az érettségi vizsgákra bocsátott öszszes diák még az állami gimnázium berkein belül le tudta tenni azt (840/1950., GYBGL, 1948-1950, 1. köteg).

Az iskolai munka maghatározó részét képezi az infrastrukturális ellátottság, a tanügyi eszközök felszereltsége és az oktatást biztosító eszközök, bútorok megléte, azok állapota. Az állami Czuczor Gergely gimnáziumnak az 1949/50-es tanévben rendelkezésre álló tanítási eszközeiről, vagyoni helyzetéről és infrastrukturális ellátottságáról bő információkkal rendelkezünk a fennmaradt levéltári forrásoknak köszönhetően.

Ideológiai szempontoknak megfelelően az iskolai könyvállományban selejtezést hajtot- 
tak végre, melynek következtében sok, fóként vallási témájú és a polgári kort idéző szépirodalmi munkákat (pl.: Szent Ágoston, Mikszáth Kálmán stb.) ítéltek szanálásra. (881/1950., GYBGL, 1948-1950, 1. köteg). A könyvállomány tekintetében mindenképpen meg kell említenünk, hogy Csukás igazgató, értesülvén a szerzetesrendek küszöbön álló feloszlatásáról, a Megyei Tanács irányában az a kéréssel fordult, hogy a volt bencés tanári könyvtár anyagát a gimnázium megkaphassa. Ugyanis az államosítás során ez a székház épületében maradt, így „kicsúszott” az államosításkor. A tanári karnak ellenben nem volt megfelelő számú szakkönyve, (úgy mint lexikonok, szótárak), ezért az igazgató nyomatékosítva kérte a könyvtár mihamarabbi átadását a gimnázium részére (1200/1950., GYBGL, 1948-1950, 1. köteg). Értelemszerűen erre már nem kerülhetett sor, hiszen az augusztus 3-án kelt kérvény után pár héttel a gimnázium visszakerült a bencés rend fenntartásába. Fontos, hogy a gimnázium épülete mellett a rendház második emeletén található volt internátusi rész is állami tulajdonba került (668/1950., GYBGL, 1948-1950, 1. köteg).

Április 6-án a gimnáziumban váratlan pénz-, vagyon- és ügykezelés vizsgálata történt, amelyről részletes jegyzőkönyvet is kiállítottak. Ebben szerepel, hogy az államosítás során a Vallás és Közoktatásügyi Minisztériumhoz került ingó és ingatlanvagyonok állapota megfelelő és hiányt nem találtak bennük. Részletes leírják a gimnázium helyiségeit az oktatási és műszaki létesítményekkel együtt. Az épületben három személy lakott, Lató Kálmán, Horváth Lajos altisztek, akik a portási és házmesteri teendőket végezték, ezért az általuk lakott helyiségek szolgálati lakásnak minősültek. Ezenkívül megjegyzik, hogy gimnáziumnak pénzbeli tartozása, illetve hátraléka nincsen (816/1950., GYBGL, 1948-1950, 1. köteg).

Fontos még megtekinteni, hogy az egyes természettudományi tárgyak oktatásához szükséges eszközök és helyiségek (laboratorium) rendelkezésre álltak-e a gimnáziumban. A fizika szaktárgy esetében fontos, hogy a fizikaszertár anyagában a háború kevés kárt okozott, az a középiskolai tanítás követelményeinek megfelelő, emellett a fizikai előadóterem felszerelése is kielégítőnek mondható (662/1950., GYBGL, 1948-1950, 1. köteg). A vegytanhoz és matematikához szükséges eszközöket a szakfelügyelő ugyancsak a középiskolai oktatásnak megfelelőnek ítélte. A vagyoni tárgyak terén még megemlítendő, hogy a tanév folyamán a gimnázium több ízben is kért csónakokat a tanulók számára a Révai Gimnázium csónakházából (150/1949-50., GYBGL, 1948-1950, 1. köteg). Ezeket a kéréseket a pénzügyigazgatóság jóváhagyta és három db. csónakot kiutalta a gimnázium számára (197/1949-50., GYBGL, 1948-1950, 1. köteg).

A háború utáni épülethiányt jól mutatja, hogy a gimnázium épületében a szülők iskolája mellett még az állami Műszaki Főiskola győri tagozata is működött, mely délutánonként három osztálytermet vett igénybe (703/1950., GYBGL, 1948-1950, 1. köteg).

Az állami Czuczor Gergely gimnázium második 1949/50-es tanéve - amint az előbbiekben láttuk a korszak viszonyaihoz képest sikeresnek mondható, hiszen megfelelő számú diákság mellet kielégítő anyagi és infrastrukturális viszonyok között tudták folytatni a munkát. A marxista - leninista ideológia, illetve a munkaverseny egyre inkább kezdett a gimnáziumba betörni, sőt mondhatni, hogy vezető ideológiává vált a hétköznapi oktatás, nevelés terén. Ez a folyamat 1950 augusztusában megszakadt az állam és a katolikus egyház közötti megállapodás értelmében. Augusztus 30-án a Magyar Népköztársaság kormánya és a Magyar Püs- 
pöki Kar képviselői aláírták a megállapodást, amely szerint a kormány biztosítja a katolikus egyház működési szabadságát és a teljes vallásszabadságot. Szeptember 7-én megszületett a megegyezés a Vallás- és Közoktatásügyi Minisztérium, valamint a Katolikus egyház képviselői között, amely egészen 1990-ig érvényben maradt. 1950. szeptember 13-án a győri áll. Ennek értelmében összesen nyolc katolikus egyházi oktatási intézmény került vissza és meghatározták a szerzetesek lehetséges maximum létszámát is, amely csak annyi lehet, amely az intézmények ellátásához feltétlenül szükséges (Gergely, 1990).

A megegyezés I. pontja szerint a bencések a pannonhalmi és győri gimnázium, a ferencesek az esztergomi és az újonnan létrejött szentendrei gimnázium, a piaristák a kecskeméti és budapesti gimnázium, a Miasszonyunkról Nevezett Szegény Iskolanővérek Kongregációja pedig a budapesti és debreceni gimnáziumuk fenntartási jogát kapták vissza (Barkó, 2014). 1950-ben a magyar bencés rend teljes létszámát 80 fóben határozták meg, a növendékség létszámát pedig 14 főben (Somorjai, 1996). 1950-ben tehát a Czuczor Gergely gimnázium megszűnt és az épületet a bencés rend visszakapta. A következő tanév (1950/51) újra a bencés rend irányításában kezdődött, a gimnázium épületét és a fenntartását visszakapta a bencés rend (1336/1950., GYBGL, 1948-1950, 1. köteg).

\section{ÖSsZEGZÉS, KONKLƯZIÓ}

Az „sikeres” államosítást és az első tanév „kísérletezéseit” követően az 1949/1950-es tanévben az állami gimnázium már szinte teljes spektrumában tudta alkalmazni azokat az oktatási és nevelői eszközöket, melyeket az kommunista hatalom megkövetelt az oktatási intézmények egészétől. A gimnázium működése és a tanév menete kezdett teljes egészében „,belesimulni” a városi- és országos iskolahálózatba, amely a lelkes és ideológiai szempontból képzett oktatói gárdának volt köszönhető, azonban a „régi” gimnáziumból megmaradt diákság világnézeti képe ezt megnehezítette. Érdekes tény, hogy a vallásos diákok és szüleik mennyire ragaszkodtak a régi tanáraikhoz, valamint a vallásos értékek és a keresztény nevelés hagyományaihoz és mely ragaszkodást nem is sikerült „elvenni” tőlük a két tanév során. A második tanév már tekinthető az Állami Czuczor Gergely Gimnázium teljes kibontakozásának, ahol az új tantervek és társadalomformáló törekvések teljes egészében kezdtek érvényre jutni.

E folyamat, ha 1950 nyarán másképpen alakulnak a belpolitikai feltételek minden bizonnyal tökéletesedet volna és a bencés gimnázium valóban a város történelmének egy darabját, szép emlékét alkotná ma. Azonban 1950 nyarán a bencések visszakapták a győri gimnáziumot így valamelyest lélegzethez jutva a diktatúra fullasztó légkörében és esélyt kapva, hogy a győri intézmény a keresztény értékek és nevelés egyik „átmentőjévé” váljon az elkövetkező negyven év államszocialista rendszerében. 1950 szeptemberében, a kommunista diktatúra talán „legnehezebb” időszakában újból megindult a bencés oktató és nevelő munka az intézmény falai között és kezdetét vette az az iskolatörténeti korszak, amikor külső politikai nyomás mellett regionális, sőt országos vonzáskörzetű iskolává, a keresztény nevelés szigetévé válik. 


\section{Polgári Szemle · 17. évfolyam 4-6. szám}

\section{FelhasZnált IRODALOM}

Barkó Gábor Ágoston (2014): Változások a Gyoóri Czuczor Gergely Bencés Gimnázium és Kollégium életében 1950-tól napjainkig. Szakdolgozat SSZHF. Hittanár-nevelő szak, ELTE PPK., Történelemtanár, Budapest, p. 88.

Bánhegyi Miksa OSB (1977): Gimnáziumunk mai élete. In: A gyóri Czuczor Gergely Bencés Gimnázium Évkönyve (1977) (szerk.: Bánhegyi Miksa OSB)., pp. 13-15.

Mészáros István (1994): ...Kimaradt tananyag...Diktatúra és az egyház 1945-1956. Márton Áron Kiadó, Budapest, pp. 128.

Ö. Kovács József (2009): A kollektivizálási kampány „szocreál” kontextusai Magyarországon (1948-1953). Aetas 24, pp. 32-46.

Rétfalvi Balázs (2017): Sárközy Pál fóapáti kinevezése http://cellbibl-digit.cellkabel.hu/retfalvy.balazs-sarkozy.pal.foapati.kinevezese.pdf letöltés: 2021. október 22.

Romsics Ignác (2010): Magyarország története a XX. században. Osiris Kiadó, Budapest, pp. 688.

Sárai-Szabó Kelemen - Fekete Dávid (2021): A győri bencés gimnázium működése a II. világháború végétől 1949-ig. Polgári Szemle, 17, 1-3, 280-294.

Somorjai Ádám (1996): A magyarországi bencés rend XX. századi történetének rövid vázlata 1983-ig. Magyar Egyháztörténeti Vázlatok 8, No. 1-2., pp. 137-148.

Tóth Konstantin (2011): A győri Czuczor Gergely Bencés Gimnázium és Kollégium életében bekövetkezett legfőbb változások az 1980-as évek végétől napjainkig. In.: Heggyel az ég egybemosódik. Ünnepi kötet Korzenszky Richárd 70. születésnapjára. (szerk.: Barkó Ágoston OSB - Somorjai Ádám OSB), Tihanyi Szent Gergely Alapítvány, Tihany, pp. 218-240.

2/1949-50. Jegyzőkönyv az 1949.évi augusztus 29-én az Állami Czuczor Gergely Gimnáziumban tartott javítóvizsgálatok alkalmával, 1949. augusztus 29., GYBGL, Gimnáziumi iratok, 1948-50. 1. köteg

1-1, 1-2,1-3,1-4,1-6/1949-50. Jegyzőkönyv, 1949. augusztus 30., GYBGL, Gimnáziumi iratok, 1948-50. 1. köteg

18/1948-49. Felmentés igazgatói teendők ellátása alól, 1949. augusztus 31., GYBGL, Gimnáziumi iratok, $1948-50$. 1. köteg

53/1949-50.sz. Jegyzőkönyv, 1949.augusztus 31., GYBGL, Gimnáziumi iratok. 1. köteg

359-423/1949-50.sz. Tanárok, Egyéb alkalmazottak, 1949.december 8., GYBGL, Gimnáziumi iratok, 1948-50. 1. köteg

180/1949/50.sz. Tantárgyfelosztás az 1949/50 iskolai évben., 1949. október 4., GYBGL, Gimnáziumi irtok, 194850. 1. köteg

5696/1949.sz. Gaál Lajos testnevelési tanár áthelyezése, 1949. október 6., GYBGL, Gimnáziumi iratok, $1948-50$.

1. köteg

38-2/1949-50.sz. Működési Bizonyítvány, 1949. szeptember 7., GYBGL, Gimnáziumi iratok, 1948-50. 1. köteg

7260/1949.sz. Koncz József úrnak, okl. középisk. rajztanár, 1949. november 26., GYBGL, Gimnáziumi iratok, 1948-50. 1. köteg

214/1949-50.sz. Jegyzőkönyv., 1949.szeptember 27., GYBGL, Gimnáziumi iratok, 1948 - 1950. 1. köteg

254/1949-50.sz. Jegyzőkönyv., 1949. október 21., GYBGL, Gimnáziumi iratok, 1948 - 1950. 1. köteg

6434./1949.sz. Győri Áll. Czuczor G. Gimn. Igazgatóságának, 1949. október 31., GYBGL, Gimnáziumi iratok, 1949 - 1950. 1. köteg

577/1950.sz. Államvédelmi Hatóság, 1950.január 21., GYGBL, Gimnáziumi iratok, 1948 - 1950.1. köteg

633/1950.sz. Jegyzőkönyv a győri áll. Czuczor Gergely gimnáziumban 1950. február hó 7 - én megtartott rendkívüli értekezletéről, 1950. február 7., GYBGL, Gimnáziumi iratok, 1948 - 1950. 1. köteg

871/1950.sz. Jegyzőkönyv, 1950. április 15., GYBGL, Gimnáziumi iratok, 1948 - 1950. 1. köteg

447/1949.sz. Jegyzőkönyv, 1949. november 21., GYGBL, Gimnáziumi iratok, 1948 - 1950. 1. köteg

427/1849.sz. Jegyzőkönyv az áll. Czuczor gimnáziumban 1949. december 7-én tartott 1. versenyértekezletről, 1949. december 8., GYGBL, Gimnáziumi iratok, 1948 - 1950. 1. köteg

465/1949.sz. Jegyzőkönyv az áll. Czuczor gimnáziumban dec. hó 15-én tartott II. versenyértekezletről, 1949.december 15., GYBGL, Gimnáziumi iratok, 1948 - 1950. 1. köteg 
246/1949-50.sz. Jegyzőkönyv a győri áll. Czuczor Gergely gimnázium tanári testületének 1949. évi október hó 11 -én tartott rendkívüli értekezletéről, 1949. október 11., GYBGL, Gimnáziumi iratok, 1948 - 1950. 1. köteg

5207/1949.sz. A vallástan, mint rendkívüli tárgy tanítása az 1949/50. iskolai évben, GYBGL, Gimnáziumi iratok, 1948 - 1950.1. köteg

817/1950.sz. Munkaterv, 1950. április 6., GYBGL, Gimnáziumi iratok, 1948 - 1950. 1. köteg

522/1950.sz. Sz.M. munkaverseny kiértékelése, 1950.január 6., GYBGL, Gimnáziumi iratok, 1948 - 1950. 1. köteg 1072-10/1950.főig.sz. Körözvény, 1950.április 27., GYBGL, Gimnáziumi iratok, 1948 - 1950. 1. köteg

91/1949.sz. Körözvény, 1949. november 3., GYBGL, Gimnáziumi iratok, 1948 - 1950. 1. köteg 468/1949-50.sz. Dolgozatok felküldése, 1949. december 19., GYGBL, Gimnáziumi iratok, 1948 - 1950. 1. köteg 6304/1949.sz. Megemlékezés az ifjúság napjáról, 1949. október 27., GYGBL, Gimnáziumi iratok, 1948 - 1950.1. köteg

766/1949-50.sz. Jegyzőkönyv, mely készült 1950. március 22-én a győri Czuczor Gergely gimnáziumban az orosz nyelvi tanulmányi felügyelet alkalmával, 1950. március 22., GYBGL, Gimnáziumi iratok, 1948 - 1950. 1. köteg 632/1950.sz. Jegyzőkönyv a győri áll. Czuczor Gergely gimnázium tanári testületének 1950. évi január hó 28-án tartott I. félévi osztályozó értekezletéről, 1950. január 28., GYBGL, Gimnáziumi iratok, 1948 -1950. 1. köteg 697/1950.sz. Jelentés február hóról, 1950.február 27., GYBGL, Gimnáziumi iratok, 1948 - 1950. 1. köteg 884/1950.sz. Április havi jelentés, 1950. április 26., GYBGL, Gimnáziumi iratok. 1948 - 1950, 1. köteg 885/1950.sz. Főigazgató Úr!, 1950. április 26., GYBGL, Gimnáziumi iratok, 1948 - 1950. 1. köteg 305/1949/50.sz. Jelentés a Szülői Munkaközösség október havi munkájáról, 1949. november 4., GYBGL, Gimnáziumi iratok, 1948 - 1950. 1. köteg 420/1949-50.sz. Jegyzőkönyv, 1949. november 24., GYBGL, Gimnáziumi iratok, 1948 -1950. 1. köteg 879/1950.sz. Jegyzőkönyv, 1950. április 18., GYBGL, Gimnáziumi iratok, 1948 - 1950. 1. köteg 840/1950.sz. Kimutatás az 1949/50. évi június havi érettségi vizsgálatra jelentkezettekről, 1950. április 15., GYBGL, Gimnáziumiiratok, 1948 - 1950. 1. köteg

881/1950.sz. Selejtezendő könyvek jegyzéke, 1950. április 24., GYBGL, Gimnáziumi iratok 1948 - 1950. 1. köteg 1200/1950.sz. Megyei Tanács IX. ügyosztályának, 1950. augusztus 3., GYBGL, Gimnáziumi iratok 1948 - 1950. 1. köteg 668/1950.sz. Jegyzőkönyv, 1950. február 18., GYBGL, Gimnáziumi iratok 1948 - 1950. 1. köteg 816/1950.sz. Jegyzőkönyv, 1950. április 6., GYBGL, Gimnáziumi iratok, 1948 - 1950. 1. köteg 662/1950.sz. Jegyzőkönyv, 1950. február 16., GYBGL, Gimnáziumi iratok 1948 - 1950. 1. köteg 150/1949-50.sz. M.Áll. Pénzügyigazgatóság, 1949. szeptember 29., GYBGL, Gimnáziumi iratok 1948 - 1950.1. köteg 40.675/4-1949.sz. Állami Czuczor Gergely Gimnázium, 1949. november 11., GYBGL, Gimnáziumi iratok 1948 - 1950. 1. köteg 197/1949-50.sz. Határozat, 1949. október 3., GYBGL, Gimnáziumi iratok 1948 - 1950. 1. köteg 703/1950.sz. VKM. IV./1. ügyosztályának, 1950. február 18., GYBGL, Gimnáziumi iratok, 1928 - 1950. 1. köteg 1336/1950.sz. Győr, 1950. szeptember 13., GYBGL, Gimnáziumi iratok 1948 - 1950.1. köteg 